\title{
The Regulation of Crop Emptying Rate in the Chicken : Effects of Administration Route of Medium Chain Triacylglycerol and Alkaline Treatment
}

\author{
Mitsuhiro FURUSE, Remedios T MABAYO \\ and Jun-ichi OKUMURA \\ School of Agricultural Sciences, Nagoya University, \\ Chikusa-ku, Nagoya-shi 464-01
}

(Received September 7, 1995)

\begin{abstract}
The mechanism by which medium chain triacylglycerol (MCT) delayed the crop emptying rate in the chicken was investigated. In the first experiment, the effect of administration route was determined. After oral or intraperitoneal administration of saline, MCT or long chain triacylglycerol, the crop emptying rate was measured. Only oral administration of MCT delayed the crop emptying compared with other treatments. The influence of alkaline $\left(\mathrm{NaHCO}_{3}\right)$ treatment on the delayed crop emptying induced by MCT was investigated in the second experiment to clarify the involvement of acidity. The alkaline treatment did not improve the crop emptying and the highest treatment of alkaline further delayed the crop emptying rate. It was suggested that the delayed crop emptying rate was induced only when MCT was administered orally, and it was not improved by alkaline treatment.
\end{abstract}

Anim. Sci. Technol. (Jpn.) 67 (2) : 142-145, 1996

Key words : Crop emptying rate, Medium chain triacylglycerol, Alkaline, Chicken

We have shown in the previous paper that crop emptying rate was delayed by dietary medium chain triacylglycerol (MCT) in chicks $^{7)}$. The mechanisms controlling the crop emptying in chicks are poorly understood. Intragastric instillation of $50 \mathrm{mM}$ hydrochloric acid ( $\mathrm{HCl}$ ) inhibited gastric emptying in rats ${ }^{3)}$. According to Greenberger et al. ${ }^{6)}$, MCT can be hydrolyzed to medium chain fatty acids (MCFA) and glycerol in the lumen. Thus, it was possible that MCFA released from MCT inhibited crop emptying.

On the other hand, Denbow et al. ${ }^{2)}$ indicated that the effect of several kinds of triacylglycerols on feeding behavior was altered by the administration routes.

The present study, therefore, was in- vestigated to clarify the effect of dietary MCT on the crop emptying rate in different administration routes, and moreover, the influence of alkaline treatment on the delayed crop emptying rate induced by $\mathrm{MCT}$ in the chicken was also investigated.

\section{Materials and Methods}

General: Day-old Single Comb White Leghorn male chicks (Hattori Hatchery, Ltd., Nagoya) were housed in wire-meshed cages. They received commercial chick mash (Marubeni Shiryo Co., Tokyo) until they were selected for each experiment. Before the start of each experiment, the chicks were fasted overnight (about $14 \mathrm{~h}$ ) with free access to water. 


\section{Crop Emptying Rate in the Chicken}

Crop emptying was examined by incision of the skin of crop and clamping the lower and upper crop junctions under light anesthesia with diethyl ether. The crop was then cut distal to the clamps, and crop content was removed and dried at $55^{\circ} \mathrm{C}$ for $24 \mathrm{~h}$ and weighed. Crop emptying rate was assessed by measuring the dry weight of a meal remaining in the crop and expressed as the relative weight of the crop content to the amount of food intubated.

Effects of administration routes: The birds ( 7 week old, $570 \pm 6 \mathrm{~g}$ ) were treated with $1 \mathrm{ml}$ of saline $(0.85 \% \mathrm{NaCl}), \mathrm{MCT}$ or LCT by gavage or by intraperitoneal injection. Just after treatments, chickens received $11 \mathrm{ml}$ slurry (basal $\operatorname{diet}$ (Table 1): water $=3: 4$ ) and crop emptying was done after $3 \mathrm{~h}$. The number of birds was 6 or 7 per treatment.

Effects of dietary $\mathrm{NaHCO}_{3}$ : The chicks (23 day old, $142 \pm 2 \mathrm{~g}$ ) received MCT diets containing $0,2.5,5$ or $10 \% \mathrm{NaHCO}_{3}$. They were intubated with $8 \mathrm{~m} l$ slurry (MCT diet (Table 1): water $=2: 3$ ) and crop emptying was done after $3 \mathrm{~h}$. NaHCO3 was supplemented to the MCT diet instead of corn starch. The number of

Table 1. Composition of experimental diets ( $\mathrm{g}$ / $\mathrm{kg}$ )

\begin{tabular}{|c|c|c|}
\hline Ingredient & Basal & $\mathrm{MCT}^{a}$ \\
\hline Isolated soybean protein & \multicolumn{2}{|c|}{226} \\
\hline Mineral mixture & \multicolumn{2}{|c|}{58.8} \\
\hline Vitamin mixture ${ }^{\mathrm{b}}$ & \multicolumn{2}{|c|}{2} \\
\hline Choline chloride & \multicolumn{2}{|c|}{1.5} \\
\hline Inositol & \multicolumn{2}{|c|}{1} \\
\hline L-Methionine & \multicolumn{2}{|c|}{2.9} \\
\hline L-Threonine & \multicolumn{2}{|c|}{1.2} \\
\hline Glycine & \multicolumn{2}{|c|}{ 4. 2} \\
\hline Cellulose & \multicolumn{2}{|c|}{100} \\
\hline Corn starch & 547.4 & 402.4 \\
\hline Corn oil & 55.0 & 20 \\
\hline Coconado $\mathrm{RK}^{(\beta) c}$ & 0 & 180 \\
\hline
\end{tabular}

${ }^{\mathrm{a}} \mathrm{MCT}$, medium chain triacylglycerol.

${ }^{b}$ Furuse and Okumura ${ }^{4}$.

${ }^{\mathrm{C}}$ Coconado $\mathrm{RK}^{\mathrm{B}}$, glyceryl tricaprylate (donated by Kao Corp., Wakayama). birds was 5 to 7 per treatment.

Statistics: The data in the experiment of administration route were subjected to twoway analysis of variance (fat source $\times$ route) and significance of difference between means was determined by $t$ test. One-way analysis of variance was applied to $\mathrm{NaHCO}_{3}$ effect study and significance of difference was assessed by Duncan's multiple range test. Values are presented as means \pm S.E.M. Statistical significance was assumed at $\mathrm{P}<0.05$.

\section{Results}

Figure 1 shows the relative crop content of chickens after intraperitoneal or oral administration of saline, MCT or LCT. A significant interaction between oil source and administration route, implying that only oral administration of MCT significantly delayed the crop emptying of chicks compared with other treat

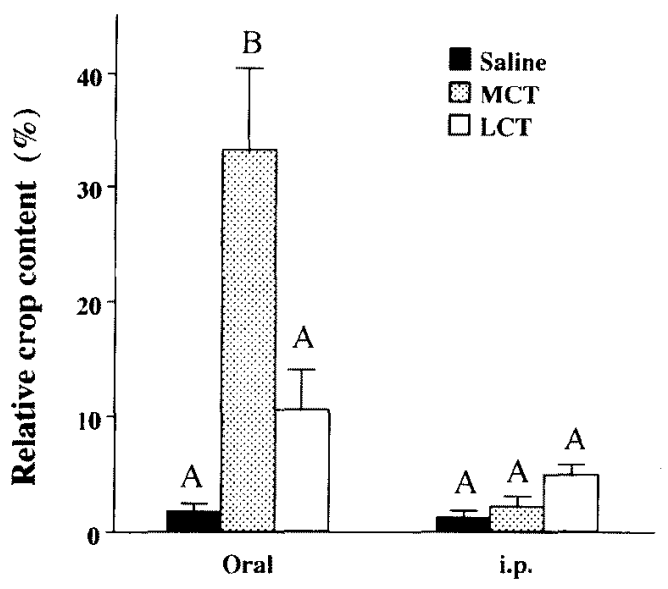

Route of administration

Fig. 1. Relative crop content of chickens after oral or intraperitoneal (i.p.) administration of saline, medium chain triacylglycerol (MCT) or long chain triacylglycerol (LCT). Just after treatments, the chicks were intubated with $11 \mathrm{ml}$ slurry (basal diet (Table 1) : water $=3: 4$ ) and crop emptying was done after $3 \mathrm{~h}$. Values are means of 6 or 7 birds \pm S.E.M. Different letters show significant difference between treatments at $\mathrm{P}<$ 0.05 . 


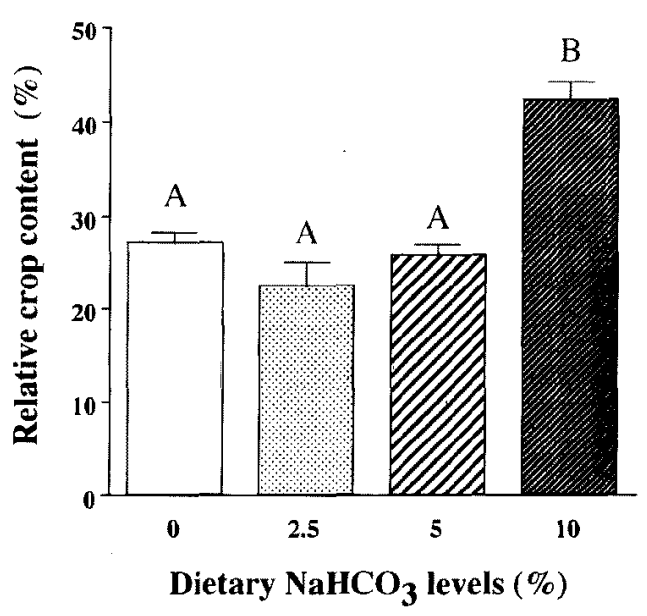

Fig. 2. Relative crop content of chickens intubated with $8 \mathrm{ml}$ slurry (MCT diet (Table 1): water $=2: 3$ ) and crop emptying was done after 3 h. $\mathrm{NaHCO}_{3}$ was supplemented to the MCT diet instead of corn starch. Values are means of 5 to 7 birds \pm S.E.M. Different letters show significant difference between treatments at $P<0.05$.

ments.

Figure 2 shows relative crop content of chicks given MCT diets containing different levels of $\mathrm{NaHCO}_{3}$. The crop emptying rate was significantly delayed when the diet containing $10 \% \mathrm{NaHCO}_{3}$ was given.

\section{Discussion}

The present study clearly demonstrated that MCT delayed the food passage from the crop only when given orally. Recently, Martinez et $a l{ }^{9)}$ reported that cholecystokinin (CCK) and chicken gastrin inhibited gastroduodenal motility in the chicken. Although it was reported that MCT enhanced the release of $\mathrm{CCK}^{7)}$, it has been demonstrated that the physiological role of CCK was not important in the chicken $^{1,10)}$. Furuse and Dockray ${ }^{5)}$ reported that MCT greatly enhanced the release of chicken gastrin. However, only pharmacological levels of gastrin inhibited the crop emptying rate in the chicken $^{8)}$. The delayed crop emptying rate induced by dietary MCT could not be explained by changes in plasma gastrin.

Acidity is one of the major regulators in the food passage. Intragastric instillation of 50 $\mathrm{mM} \mathrm{HCl}$ inhibited gastric emptying in the rats of which acid secretion was normal ${ }^{3)}$. On the other hand, the addition of $\mathrm{HCl}$ enhanced crop emptying in achlorhydric chickens which should have mimicked the role of the proventriculus ${ }^{8)}$. $\mathrm{HCl}$ might stimulate the crop emptying at physiological conditions. MCT was easily hydrolyzed in the lumen and produces $\mathrm{MCFA}^{6}$. Thus, $\mathrm{NaHCO}_{3}$ was applied to reduce the effect of $\mathrm{MCFA}$, but $\mathrm{NaHCO}_{3}$ did not improve the crop emptying rate. The crop emptying rate was further delayed by the application of the highest level of $\mathrm{NaHCO}_{3}$, which could be due to the inhibition of intestinal villous motility by alkaline treatment ${ }^{11}$. This result implied that the effect of MCT on the crop emptying rate was not influenced by acidity. The mechanisms by which MCT delays crop emptying rate in the chicken remain to be investigated in the future.

\section{Acknowledgement}

This study was supported by grant-in-aid (06660352) for scientific research from the Ministry of Education, Science and Culture, Japan.

\section{References}

1) Choi YH, Furuse M, Satoh S, Okumura J. Endogenous cholecystokinin is not a major regulator of food intake in the chicken. J. Comp. Physiol. B, $164:$ :25-429. 1994.

2) Denbow DM, Van Krey HP, Lacy MP, Watkins BA. The effect of triacylglycerol chain-length on food intake in domestic fowl. Physiol. Behav., 51 : 1147-1150. 1992.

3) Forster ER, Green T, Elliot M, Bremner A, Dockray GJ. Gastric emptying in rats : role of afferent neurons and cholecystokinin. Am. J. Phyisol., 258 : G552-G556. 1990.

4) Furuse M, Okumura J. Effect of dietary acetic acid levels on protein and energy utilization in chicks. Poult. Sci., $68:$ 795-798. 1989.

5) Furuse M, Dockray GJ. The regulation of gastrin secretion in the chicken. Regul. Pept., 55 : 253-259. 1995. 
6) Greenberger NJ, Rodgers JB, Iseelbacher KJ. Absorption of medium and long chain triglycerides: factors influencing their hydrolysis and transport. J. Clin. Invest., 45:217-227. 1966.

7) Mabayo RT, Furuse M, Yang SI, Okumura J. Medium chain triacylglycerols enhance release of cholecystokinin in chicks. J. Nutr., $122:$ 1702-1705. 1992.

8) Mabayo RT, Furuse M, Okumura J. Inhibition of food passage by omeprazole in the chicken. Eur. J. Pharmacol., 273 : 161-165. 1995.

9) Martinez V, Jimenez M, Gonalons E, Vergara P.
Effects of cholecystokinin and gastrin on gastroduodenal motility and coordination in chickens. Life Sci., 52 : 191-198. 1993.

10) Satoh S, Furuse M, Choi YH, Okumura J. Cholecystokinin is not a major regulator in the digestive system in the chicken. Experientia, $50: 812-814.1994$.

11) Womack WA, Kvietys PR, Granger DN. Villous motility. In : Handbook of physiology. Section 6. The gastrointestinal system. vol. I. (Schultz SG ed.) 975-986. Oxford University Press. New York. 1989.

\title{
ニワトリにおける飼料のそ囊通過速度の制御 : 中鎖脂肪の 投与経路とアルカリ処理の影響
}

\author{
古瀬充宏・ Mabayo RT · 奥村純市
}

名古屋大学農学部, 名古屋市千種区 464-01

\begin{abstract}
ニワトリに中鎖脂肪を与えるとそ保からの飼料の通過が遅延することが知られている．そこで中鎖脂 肪の効果は，投与経路により異なるのかどうかを最初に調查した．生理的食塩水，中鎖脂肪あるいは長

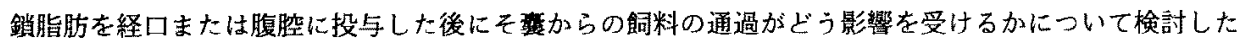
ところ，中銷脂肪を経口で投与するとその他の好理に比して有意に晕延することが判明した，次にこの 遅延が中鎖脂肪から産生された脂肪酸の影翼かどうかを明らかにするために，アルカリ( $\left.\mathrm{NaHCO}_{3}\right) に$ よる緩和効果を調べた，中鎖脂肪による飼料通過の遅延はアルカリ処理により緩和されることなく，む しろ最す高いアルカリ処理によりさらに遅れることが半明した。
\end{abstract}

日畜会報，67(2)：142-145, 1996 